\title{
Effect Of Asset Management Efficiency On Performance of Building And Construction Companies In Nigeria
}

\author{
Akparhuere Godwin Oghenekohwo \\ Department of Accountancy, Federal School of Statistics. \\ Amechi-Uno, Enugu, Nigeria. \\ Duru Nwakaego Anastesia (Ph.D) \\ Department of Accountancy, \\ Enugu State University of Science \& Technology, Enugu, Nigeria. \\ Ogbu Moses \\ Department of Accountancy, Benue State Polytechnic \\ Ugbokolo, Benue State, Nigeria
}

\begin{abstract}
The efficiency of asset management for various reasons has been the focus of companies, managers and investors doing building and construction business in Nigeria. The main objective of this study was to ascertain the effect of asset management efficiency on corporate performance of building and construction companies in Nigeria. To accomplish the main objective three specific objectives were formulated. These include examining the effects of asset turnover, inventory turnover and working capital turnover on profit after tax (proxy for performance). The study adopted the ex-post facto research design and secondary data were collected on the independent and dependent variables for ten (12) years, i.e. 2006-2017. The data were analyzed using simple regression method and it was found that net asset turnover and working capital turnover did not have significant effect on performance of building and construction companies in Nigeria. On the other hand, inventory turnover had significant effect on corporate performance of building and construction companies of Nigeria. It was recommended that management of building and construction companies should among other things adopt modern techniques of asset management that would translate asset turnover to corporate performance.
\end{abstract}

Key words: Efficiency, asset management, corporate performance

\section{Background of the Study}

\section{INTRODUCTION}

The Building and Construction sector is very crucial in any nation's social and economic development. There are many factors responsible for this. Apart from the sector's potential with respect to employment generation, the various activities undertaken in the building and construction sector are very germane (or relevant) to fostering effective sectoral linkages and enhancing, as well as sustaining economic development. For instance, efforts at ensuring sound and sustainable national and economic development cannot ignore the importance of infrastructural development (transportation-road, rail, air, and sea modes), industrial development (construction of industrial parks and factories), as well as construction of institutional buildings and provision of accommodation with respect to construction of various types of buildings, among others. In the view of Adeagbo (2014), these are areas where the building and construction sector is indispensable. 
The Building and Construction sector has been relevant in the development of the Nigerian economy. In Nigeria, the construction sector has provided employment for different categories of employees, especially in major Nigerian cities where construction activities have been immense. These include the Federal Capital Territory (FCT), Abuja, the various State capital cities like Lagos, Port-Harcourt, Ibadan, Kaduna, Kano, among others. The sector is also pivotal in sectoral linkage as its activities have multiplier effects on the growth of other sectors, especially the building materials industry, real estate transactions, among others. More importantly, the drive towards achieving the goal and objectives of the Nigerian Vision 20:2020 blueprint has an anchor in the building and construction sector. In the blueprint, infrastructural development is recognized as key to achieving economic transformation. Most of the activities lined up to be undertaken have strong role for the building and construction sector. Efforts at transforming the power, transport, housing and industrial sectors are not likely to bear the desired fruits without the active participation of the actors in the building and construction sector as well as the effective and efficient performance of the sector (Adeagbo, 2014).

'Asset management efficiency' simply called 'efficiency ratios' are ratios used to determine how well assets perform to grow businesses. Asset management ratios are the key to analyzing how effectively and efficiently a business is managing its assets to produce sales. Asset management ratios are also called turnover ratios or efficiency ratios.

When you analyze your asset management ratios, you can look at your total asset turnover ratio and if there is a problem, you can go back to your other asset management ratios and isolate the problem. Knowing your position regarding the efficiency of using assets to make sales is crucial to the success of your firm (Peavler, 2017). Asset management efficiency ratios range from asset turnover ratios (i.e. total and fixed assets turnover) to inventory turnover ratio, sales turnover ratio, receivables turnover ratio, and net working capital turnover ratio. These are financial ratios that help to determine the efficiency and effectiveness of asset management of any organization with regards to a particular period.

\section{Statement of the Problem}

The efficiency of asset management for various reasons has been the focus of companies, managers and investors doing building and construction business in Nigeria. The building and construction industry is also one of the economic sectors in Nigeria that is currently facing many challenges pertaining to corporate performance. Nigeria is currently trying to diversify its economy from the usual oil dominated economy to some other key performing and revenue generating production activities of which the building and construction companies are paramount. But how does this work out when the prevalent asset management situation in the building and construction companies in Nigeria is not determined? This is the reason why we have chosen to examine the effect of asset management efficiency on corporate performance of this sector in Nigeria.

\section{Objectives of the Study}

The broad objective of this study is to ascertain the effect of asset management efficiency on corporate performance of building and construction companies in Nigeria. To achieve this, the following specific objectives have been formulated and read thus:

1. To examine the effect of total assets turnover on corporate performance of building and construction companies in Nigeria.

2. To determine the effect of inventory turnover on corporate performance of building and construction companies in Nigeria. 
3. To verify the effect of working capital turnover on corporate performance of building and construction companies in Nigeria.

\section{Research Questions}

1. What effect does total assets turnover have on corporate performance of building and construction companies in Nigeria?

2. What effect does inventory turnover have on corporate performance of building and construction companies in Nigeria?

3. What effect does working capital turnover have on corporate performance of building and construction companies in Nigeria?

\section{Statement of Hypothesis}

The following statement of hypothesis made in null form, is to test the research questions:

1. Total assets turnover does not have significant effect on corporate performance of building and construction companies in Nigeria.

2. Inventory turnover do not have significant effect on corporate performance of building and construction companies in Nigeria.

3. Working capital turnover does not have significant effect on corporate performance building and construction companies in Nigeria.

\section{Significance of the Study}

This study is significant to the managers of resources in the construction industry. They are the primary beneficiaries with regards to the outcome and recommendations of this study. They will be able to apply such recommendations to their short- and long-term decision making process.

The owners of shares in building and construction companies will also find this study useful. The knowledge gained will be able to keep them abreast with the true situation of corporate performance and whether their investments are secure as well as capable of yielding dividends or returns in the end.

Many stock market speculators are looking for every opportunity to put their money into good use by paying or buying the shares of performing businesses as well as stay away from poorly performing ones. This study is capable of helping prospective investors to take decision whether or not to invest in the building and construction companies in Nigeria.

The study has contributed knowledge to the existing pool of empirical works on this topic. Future researchers will be able to have access to available data, methodology and recommendations provided in this study. The study also reveals important information that may be of general interest to the public in Nigeria.

\section{Scope of the Study}

The study covered asset management efficiency with respect to corporate performance of building and construction companies for the period 2006-2017. It is concerned with effects of total assets, inventory and working capital turnovers on the performances of building and construction companies for the period under reference. The study was carried out in Nigeria.

\section{Limitations of the Study}

This study is limited by sample size or total number of firms used for the analysis, and it is also constrained by the number of years covered. Other limitations include inadequate financial 
resources and scarcity of data. However, the researchers were able to manage these constraints by adopting the most convenient sampling technique and sourced for funds to cover the cost of internet subscriptions and relevant materials.

\section{Conceptual Review \\ Asset Management}

Asset Management is the combination of management, financial, economics, engineering and other practices applied to physical assets with the objective of providing the required level of service in the most cost effective manner. It includes the management of the whole life cycle (design, construction, commissioning, operating, maintaining, repairing, modifying, replacing and decommissioning/disposal) of physical and infrastructure assets. There are two main reasons for asset management: (1) To fulfill legislative, regulatory, audit, and reporting requirements; and (2) To strive to ensure assets are managed in the most cost effective, safe \& ratepayer acceptable way possible (The local Government and Municipal Knowledge Base, 2017).

According to the Institute of Asset Management (IAM), Asset Management involves the balancing of costs, opportunities and risks against the desired performance of assets, to achieve the organizational objectives. This balancing might need to be considered over different timeframes.

Asset management also enables an organization to examine the need for, and performance of, assets and asset systems at different levels. Additionally, it enables the application of analytical approaches towards managing an asset over the different stages of its life cycle (which can start with the conception of the need for the asset, through to its disposal, and includes the managing of any potential post disposal liabilities).

Asset Management is the art and science of making the right decisions and optimizing the delivery of value. A common objective is to minimize the whole life cost of assets but there may be other critical factors such as risk or business continuity to be considered objectively in this decision making. Even a fairly superficial survey of uses for the term "Asset Management" reveals some fundamental differences in interpretation and usage. Here are 6 distinct yet common current uses of the term presented by Woodhouse (2006):

1. The financial services sector has long used the phrase to describe the management of a stock or investment portfolio - trying to find the best mix of capital security/growth and interest rates/yield.

2. Main board [usually financial directors] and some city analysts use the term in relation to mergers and acquisitions- buying and selling companies, re-organizing them, divesting low value elements and trying to raise capital value and/or yields.

3. Equipment maintainers have also adopted the name (particularly in the US) in order to gain greater credibility and visibility for their activities. Maintenance has for so long been treated as a necessary evil and it is low on the budgeting priority list, therefore Asset Management sounds more professional and value-adding. Note that maintenance has an important part to play, but it's really only one of the variables in managing assets (others include, for example, choosing the right assets in the first place, using them appropriately, or trading short-term performance against long-term sustainability etc).

4. In line with the maintainers seeking greater corporate credibility, the large number of software vendors selling asset information management systems (including asset registers, GIS systems, work management, history gathering, materials control \& cost reporting etc) have often relabeled their products as "Enterprise Asset Management 
Systems". This has given rise to a misconception that Asset Management is a technology initiative to sort out the data and IT infrastructure (often leading to great expense and the 'tail wagging the dog').

5. If we dig deeper into the information systems world, we even find "Asset Management" interpreted as simply the bar-code labeling of computers and peripherals, and the tracking of their location/status (i.e. 'asset tracking').

6. Finally, a few critical infrastructure or plant owners and operators have adopted the term 'Asset Management' to describe their core role in life - both caring for, and making best sustained use of, physical plant, infrastructure and its associated facilities. This is the interpretation that the new British Standard, PAS-55 is focused upon, and is the subject of this article.

Vanier (2001) has defined asset management broadly as "any system that monitors and maintains things of value to an entity or group or ethnic groups. It may apply to both tangible assets such as buildings and to intangible assets such as human capital in general intellectual property, and goodwill and financial assets....Asset management is a systematic process of deploying, operating, maintaining, upgrading, and disposing of assets cost-effectively or ineffectively. The term is most commonly used in the financial world to describe people and companies that manage investments on behalf of others. These include, for example, investment managers that manage the assets of a pension fund."

Alternative views of asset management in the engineering environment are: the practice of managing assets to achieve the greatest return (particularly useful for productive assets such as plant and equipment), and the process of monitoring and maintaining facilities systems, with the objective of providing the best possible service to users in all dimensions (appropriate for public infrastructure assets).

\section{Corporate Performance}

Corporate performance is a composite assessment of how well an organization executes on its most important parameters, typically financial, market and shareholder performance. Corporate performance analysis is a subset of business analytics/business intelligence (BA/BI) that is concerned with the "health" of the organization, which has traditionally been measured in terms of financial performance. However, in recent years, the concept of corporate health has become broader.

Like the concept of business sustainability, corporate health is now considered to involve not only financial considerations but also other factors including social responsibility and reputation, innovation, employee morale and productivity. As such, performance is no longer measured only on key performance indicators (KPI) such as revenue, return on investment (ROI), overhead and operational costs (Rouse, 2015).

\section{Asset Turnover Ratio}

According to Kenton and Hayes (2019) defined asset turnover ratio as "a measure of the value of a company's sales or revenues relative to the value of its assets. The asset turnover ratio can be used as an indicator of the efficiency with which a company is using its assets to generate revenue. The higher the asset turnover ratio, the more efficient a company is. Conversely, if a company has a low asset turnover ratio, it indicates it is not efficiently using its assets to generate sales." 
Borad (2017) also opined that asset turnover ratio is "a ratio that indicates how efficiently a business is using its fixed assets. It rates its operational performance relative to its investment in fixed assets. In simple words, it expresses revenue per dollar of fixed assets in the books. This metric is more useful in manufacturing industry because of the sizeable investment in the plant, property and equipments."

\section{Inventory Turnover ratio}

Hargrave (2019) defines inventory turnover ratio as "a ratio showing how many times a company has sold and replaced inventory during a given period... measures how fast a company sells inventory and how analysts compare it to industry averages." This implies that a low turnover ratio represents a weak sales and possibly excess inventory or overstocking. On the other hand, a high turnover ratio implies a strong sales or insufficient inventory. Low inventory is sometimes preferred to high inventory because it is a sign that shortages are expected.

My Accounting Course (n.d.) has also described inventory turnover ratio as "an efficiency ratio that shows how effectively inventory is managed by comparing cost of goods sold with average inventory for a period...it measures how many times average inventory is 'turned' or sold during a period."

\section{Working Capital ratio}

This is a measure of a firm's liquidity or ability to pay debts or meet its obligations. In other words, it relates the current assets with current liabilities of a firm to ascertain whether the former is able to pay for the liabilities. An increase in the ratio indicates that the company has probably gone through a fast expansion over the past few years and added both receivables and inventory while a decrease shows otherwise (My Accounting course online, n.d.).

According to Kenton (2019) "working capital turnover is a ratio that measures how efficiently a company is using its working capital to support a given level of sales. Also referred to as net sales to working capital, work capital turnover shows the relationship between the funds used to finance a company's operations and the revenues a company generates as a result."

\section{Markowitz Portfolio Theory (1952)}

\section{THEORETICAL FRAMEWORK}

Henry Markowitz developed the portfolio model in 1952. This model not only expected returns but also includes the level of risk for a particular return. Markowitz assumed the following about an individual's investment behaviour:

1. Given the same level of expected return, an investor will choose the investment with the invested amount of risk.

2. Investors measure risk in terms of an investment variance or standard deviation.

3. For each investment, the investor can quantify the investment's expected return and the possibility of those returns over a specified time horizon.

4. Investors seek to average their utility.

5. Investors make decisions based on an investment's risk and return, therefore an investor's utility curve is based on risk and return.

\section{Empirical Review}

This study takes a look at the contributions made by other researchers on this and related subject matter. Several works have been carried out on the issue of asset management and it is only necessary or importation to closely examine some of the empirical studies in order to possibly locate the gaps that may exist. 
Olatunji and Adegbite (2014) examined the effect of investment in fixed assets on profitability of selected Nigerian banks as well as the significant components of fixed assets investment of selected Nigerian Commercial Banks. Data were obtained from annual reports and accounts of selected Nigerian commercial Banks. Pearson product moment correlation and multiple regressions were employed to analyze the relationship between the dependent variable (Net profit) and independent variables (Building, Land, Leasehold premises, fixtures and fitting, and investment in computers.). Findings show that there was a significant relationship between dependent variable (Net Profit) and the independent variables (Building, information communication and technology, machinery, leasehold, land and fixture and fitting). Therefore, investments in fixed assets have strong and positive statistical impact on the profitability of banking sector in Nigeria. In order to improve bank profitability through efficient management of fixed assets, Nigerian banks were advised to increase fixed assets investments in form of ICT. Akeem, Terer, Kiyanju \& Kayode (2014) examined the effect of capital structure on firm's performance with a case study of manufacturing companies in Nigeria from 2003 to 2012 with the purpose of providing a critical appraisal of the need and importance of capital structure. Descriptive and regression research technique was employed to consider the impact of some key variables such as Returns on asset (ROA), Returns on equity(ROE),Total debt to total asset(TD), Total debt to equity ratio(DE) on firm performance. Secondary data was employed using data derived from ten (10) manufacturing companies. From the findings, it was observed that capital structure measures (total debt and debt to equity ratio) are negatively related to firm performance. It was recommended that firms should use more of equity than debt in financing their business activities, in as much as the value of a business can be enhanced using debt capital. Hence firms should establish the point at which the weighted average cost of capital is minimal and maintain that gearing ratio so that the company's value will not be eroded, as the firm's capital structure is optimal at this point ceteris paribus.

Al-Ani (2014) examined the effects of assets structure (fixed assets and current assets) on the financial performance of some manufacturing companies listed on Muscat Securities Market (MSM). The methodology of the study is content analysis of annual reports of a sample of 28 out of $70(40 \%)$ companies for the period 2008-2012. The assets structure is measured by fixed assets turnover and current assets turnover while the financial performance is measured by return on assets (ROA) and return on equity (ROE). The study examines two main hypotheses. The first one examines the effects of total assets turnover on ROA whereas the second one examines the effects of total assets turnover on ROE. The overall result for the study is that the structure of assets does not have a strong impact on profitability in terms of ROE. This result means that if the structure of assets is changing then the ROA will not change. Another result of the study indicates that only the fixed assets have impact on ROE unlike ROA. Another result of the study suggests that the effect of asset structure has an impact on ROE only in petro-chemical sector.

Adamu, Zubairu, Ibrahim and Ibrahim (2011) determined the influence of diversification on the performance of some Nigerian construction firms. Financial statements from seventy construction firms were analyzed. The specialization ratio method was used to measure and categorize the firms into undiversified, moderately diversified and highly diversified firms, and profitability ratios were used to measure the group-wise performance of the firms. The Student t-test was used to test the relationship between the extent of diversification and performance. The findings revealed that undiversified firms outperform the highly diversified firms in terms of Return on Total Assets and Profit Margin. Similarly, the moderately diversified firms were found to outperform the highly diversified firms in terms of Return on Equity, Return on Total Assets and Profit Margin. However, no performance difference was found between the 
undiversified firms and the moderately diversified firms based on the three measures used. A nonlinear relationship was found between the extent of diversification and performance. It was concluded that diversification does not necessarily lead to an improvement in profitability. The implication is that firms are better-off remaining focused if the aim is to improve financial performance.

Sitienei and Memba (2015) evaluated the effects of inventory management on the profitability of the Cement manufacturing firms in Kenya. A cross sectional data from 1999 to 2014 was gathered for the analysis of the annual reports for the three sampled firms listed at Nairobi Securities Exchange (NSE). The ordinary least squares (OLS) stated in the form of a multiple regression model was applied in the data analysis to establish the relationship between inventory management and firm's profitability. The variables used include inventory turnover, inventory conversion period, Inventory levels, storage cost, size of firm, gross profit margin, Return on assets and growth of firm. The results provide a negative relationship between inventory turnover, inventory conversion period and storage cost with profitability of the company. In addition, inventory level was found to be directly related to firm's size and storage cost. The study recommends that the Cement-manufacturing firms in Kenya should strive to ensure that the right stock is kept in their warehouses to hedge against excessive holding cost and stock-outs.

Tauseef, Lohano and Khan (2015) examined the effect of debt financing on firm's financial performance, measured as return on equity, using panel data of 95 textile companies in Pakistan from 2002-03 to 2007-08. Empirical results show a nonlinear relationship between return on equity and debt-to-asset ratio. As the debt-to-asset ratio increases, initially the return on equity increases until an optimal debt level is reached, after that it starts decreasing. The optimal debt-to-asset ratio for Pakistan's textile firms is estimated as 56 percent. We also find that firm's sales growth has positive and significant impact on return on equity whereas the firm size has no significant impact on it.

Ongore and Kusa (2013) studied moderating effect of ownership structure on bank performance. To fill this glaring gap in this vital area of study, the authors used linear multiple regression model and Generalized Least Square on panel data to estimate the parameters. The findings showed that bank specific factors significantly affect the performance of commercial banks in Kenya, except for liquidity variable. But the overall effect of macroeconomic variables was inconclusive at 5\% significance level. The moderating role of ownership identity on the financial performance of commercial banks was insignificant. Thus, it can be concluded that the financial performance of commercial banks in Kenya is driven mainly by board and management decisions, while macroeconomic factors have insignificant contribution.

Davydoff, Gabaut and Naacke (2011) analyzed and estimated the contribution of the asset management industry to the real economy. The study considered that financial systems: 1 . Produce information ex ante about possible investments and allocate capital; 2 . Mobilize and pool savings, and facilitate trading, diversification and risk management; and 3. Monitor investments and exert corporate governance after providing finance. The study revealed that professionally managed assets in Europe amounted to EUR 12.800 billion in 2009, in other words around $30 \%$ of the global asset management industry. On the other side of the economy, namely economic players that need financing, $37 \%$ of the free float market capitalization of listed European companies is held by investment funds or institutional investors in the framework of a mandate. It was estimated the contribution of the asset management industry to the overall equity financing of listed and non-listed non-financial European companies as $21 \%$ at the end of 2009 . 
Mardiasmo, Tywonia, Brown and Burgess (2008) investigated how engineering and governance perspectives of asset management can be reconciled and integrated to enable optimal asset and organizational performance. Preliminary findings of a pilot study identifies issues in asset management process and localized understanding of governance within different organization divisions as the main challenges in asset management-asset governance integration.

Ferreira, Matos and Pires (2017) studied the performance of equity mutual funds run by asset management divisions of commercial banking groups using a worldwide sample. The results show that bank-affiliated funds underperform unaffiliated funds by 92 basis points per year. Consistent with conflicts of interest, the underperformance is more pronounced among those affiliated funds that overweight more the stock of the bank's lending clients. Divestitures of asset management divisions by banking groups support a causal interpretation of the results. The findings suggest that affiliated fund managers support their lending divisions' operations to reduce career concerns at the expense of fund investors.

Campello (2005) looked at moral hazard in Örm performance under external financing. The testing strategy I implement sidesteps the issue of endogeneity between financial contracting and economic outcomes by using asset tangibility (i.e., the resale value or ease of redeployment of the financial assets) as a state variable. The study showed novel evidence that the performance of externally-funded investment is driven by the post-financing value/redeployability of the Örmís assets outside of the Örm. More precisely, it showed that the component of investment that is explained by external financing is associated with superior Örm product market performance, valuation, and accounting returns when, subsequently to financing, asset tangibility turns out to be high. In contrast, economic outcomes associated with external funding are markedly poorer when asset tangibility is ex-post low. Crucially, these dynamics are not observed for internally-funded investment. Inferences that the Örm observes superior business performance under external financing when assets are more tangible hold for both new outside equity and debt financing.

Massa and Zhang (n.d.) studied how the strategies and performance of an asset management company are affected by its internal organizational structure. Relying on Stein's (2002) theory of organizations, the researchers argue that a more hierarchical structure reduces the incentives to collect "soft" information and to engage in proximity investment. This should lower portfolio concentration, increase managerial herding and reduce performance. The study used information on the organizational structure of all the US mutual funds and insurance-managed funds investing in US corporate bonds. The analysis showed that more hierarchical structures invest less in firms located close to them and deliver lower performance, and an additional layer in the hierarchical structure reduces the average performance by 24 basis points per month. At the same time, more hierarchical structures tend to herd more and to hold less concentrated portfolios. It was also found that changes in fund structure quickly find their way into the behavior of fund managers. Overall, the organizational structure affects performance slightly more for mutual funds than insurance-managed funds, while it impacts proximity investment, herding and portfolio concentration more for insurance-managed funds than mutual funds.

Shah and Littlefield (2009) examined asset performance management as a means of aligning the goals of Chief Financial Officers (CFO's) and Maintenance Managers in organizations. The researchers surveyed 139 executives in October 2009 to understand their asset management programs and the results revealed that in more than $70 \%$ of the responding companies, the 
capital and operational budgets have either remained the same or decreased by as much as $20 \%$ as compared to last year. The report highlighted how Best-in-Class companies are able to manage the reliability of their asset base in this environment by effectively executing an Asset Performance Management (APM) strategy, resulting in higher operational and financial performance.

Carlucci and Schiuma (2004) explored a fundamental issue as the basis of the reasons for the implementation of Knowledge Management (KM) initiatives within companies that is business performance improvement. In particular, the research provided a framework which aims to drive management in planning and evaluating a KM initiative focused on the improvement of a specific business performance. 
Table 2.1: Summary of Literature Review

\begin{tabular}{|c|c|c|c|}
\hline AUTHOR(S)/YEAR & TITLE OF WORK & $\begin{array}{l}\text { METHOD OF } \\
\text { ANALYSIS } \\
\end{array}$ & FINDINGS \\
\hline $\begin{array}{l}\text { Massa and Zhang } \\
\text { (n.d.) }\end{array}$ & $\begin{array}{l}\text { The effects of the } \\
\text { organizational structure on } \\
\text { asset management }\end{array}$ & $\begin{array}{l}\text { Interview and } \\
\text { observation } \\
\text { analysis method }\end{array}$ & $\begin{array}{l}\text { More hierarchical structures invest } \\
\text { less in firms located close to them } \\
\text { and deliver lower performance, and } \\
\text { an additional layer in the } \\
\text { hierarchical structure reduces the } \\
\text { average performance by } 24 \text { basis } \\
\text { points per month; changes in fund } \\
\text { structure quickly find their way } \\
\text { into the behavior of fund managers }\end{array}$ \\
\hline $\begin{array}{l}\text { Carlucci and } \\
\text { Schiuma (2004) }\end{array}$ & $\begin{array}{l}\text { Managing knowledge for } \\
\text { business performance } \\
\text { improvement }\end{array}$ & Survey analysis & $\begin{array}{l}\text { Provided a framework which aims } \\
\text { to drive management in planning } \\
\text { and evaluating a KM initiative } \\
\text { focused on the improvement of a } \\
\text { specific business performance. }\end{array}$ \\
\hline Campello 2005) & $\begin{array}{l}\text { Asset tangibility and } \\
\text { corporate performance under } \\
\text { external financing }\end{array}$ & $\begin{array}{l}\text { Simple } \\
\text { regression } \\
\text { analysis }\end{array}$ & $\begin{array}{l}\text { The performance of externally- } \\
\text { funded investment is driven by the } \\
\text { post-financing value/redeploy- } \\
\text { ability of the Örmís assets outside } \\
\text { of the Örm }\end{array}$ \\
\hline $\begin{array}{l}\text { Mardiasmo, } \\
\text { Tywonia, Brown and } \\
\text { Burgess (2008) }\end{array}$ & $\begin{array}{l}\text { Asset management and } \\
\text { governance: Analyzing } \\
\text { vehicle fleets in asset- } \\
\text { intensive organizations }\end{array}$ & $\begin{array}{l}\text { Field study and } \\
\text { interview }\end{array}$ & $\begin{array}{l}\text { Issues in asset management } \\
\text { process and localized } \\
\text { understanding of governance } \\
\text { within different organization } \\
\text { divisions as the main challenges in } \\
\text { asset management-asset } \\
\text { governance integration }\end{array}$ \\
\hline $\begin{array}{l}\text { Shah and Littlefield } \\
\text { (2009) }\end{array}$ & $\begin{array}{l}\text { Asset performance } \\
\text { management: Aligning the } \\
\text { goals of CFO's and } \\
\text { Maintenance Managers }\end{array}$ & Survey analysis & $\begin{array}{l}\text { Asset Performance Management } \\
\text { (APM) strategy, resulting in higher } \\
\text { operational and financial } \\
\text { performance. }\end{array}$ \\
\hline $\begin{array}{l}\text { Adamu, Zubairu, } \\
\text { Ibrahim and } \\
\text { Ibrahim (2011) }\end{array}$ & $\begin{array}{l}\text { Evaluating the impact of } \\
\text { product diversification on } \\
\text { financial performance of } \\
\text { selected Nigerian } \\
\text { construction firms }\end{array}$ & $\begin{array}{l}\text { Specialization } \\
\text { ratio }\end{array}$ & $\begin{array}{l}\text { Undiversified firms outperform the } \\
\text { highly diversified firms in terms of } \\
\text { Return on Total Assets and Profit } \\
\text { Margin }\end{array}$ \\
\hline $\begin{array}{l}\text { Davydoff, Gabaut } \\
\text { and Naacke (2011) }\end{array}$ & $\begin{array}{l}\text { The importance of asset } \\
\text { management to the European } \\
\text { economy }\end{array}$ & $\begin{array}{l}\text { Observation and } \\
\text { interview }\end{array}$ & $\begin{array}{l}\text { Professionally managed assets in } \\
\text { Europe amounted to EUR } 12.800 \\
\text { billion in } 2009\end{array}$ \\
\hline
\end{tabular}




\begin{tabular}{|c|c|c|c|}
\hline $\begin{array}{l}\text { Ongore and Kusa } \\
\text { (2013) }\end{array}$ & $\begin{array}{l}\text { Determinants of financial } \\
\text { performance of commercial } \\
\text { banks in Kenya, }\end{array}$ & $\begin{array}{l}\text { Linear multiple } \\
\text { regression model } \\
\text { and Generalized } \\
\text { Least Square }\end{array}$ & $\begin{array}{l}\text { Bank specific factors significantly } \\
\text { affect the performance of } \\
\text { commercial banks in Kenya, except } \\
\text { for liquidity variable. }\end{array}$ \\
\hline $\begin{array}{l}\text { Olatunji \& Adegbite } \\
\text { (2014). }\end{array}$ & $\begin{array}{l}\text { Investment in fixed assets } \\
\text { and firm profitability: } \\
\text { Empirical evidence from the } \\
\text { Nigerian banking sector. }\end{array}$ & $\begin{array}{l}\text { Pearson product } \\
\text { moment } \\
\text { correlation and } \\
\text { multiple } \\
\text { regressions } \\
\end{array}$ & $\begin{array}{l}\text { There was a significant relationship } \\
\text { between dependent variable (Net } \\
\text { Profit) and the independent } \\
\text { variables }\end{array}$ \\
\hline $\begin{array}{l}\text { Akeem, Terer, } \\
\text { Kiyanju \& Kayode } \\
\text { (2014) }\end{array}$ & $\begin{array}{l}\text { Effect of capital structure on } \\
\text { firm's performance with a } \\
\text { case study of manufacturing } \\
\text { companies in Nigeria from } \\
2003 \text { to } 2012\end{array}$ & $\begin{array}{l}\text { Descriptive and } \\
\text { regression } \\
\text { research } \\
\text { technique }\end{array}$ & $\begin{array}{l}\text { Capital structure measures (total } \\
\text { debt and debt to equity ratio) are } \\
\text { negatively related to firm } \\
\text { performance. }\end{array}$ \\
\hline $\begin{array}{l}\text { Al-Ani (2014) } \\
\text { Continuation of }\end{array}$ & $\begin{array}{l}\text { Effects of Assets Structure on } \\
\text { the Financial Performance: } \\
\text { table le } \\
\text { Evidence from Sultanate of } \\
\text { Oman }\end{array}$ & Content Analysis & $\begin{array}{l}\text { The structure of assets does not } \\
\text { have a strong impact on } \\
\text { profitability in terms of ROE. }\end{array}$ \\
\hline $\begin{array}{l}\text { Sitienei and Memba } \\
(2015)\end{array}$ & $\begin{array}{l}\text { The effect of inventory } \\
\text { management on profitability } \\
\text { of cement manufacturing } \\
\text { companies in Kenya: A case } \\
\text { study of listed cement } \\
\text { manufacturing companies in } \\
\text { Kenya }\end{array}$ & $\begin{array}{l}\text { Ordinary least } \\
\text { squares (OLS) } \\
\text { stated in the } \\
\text { form of a } \\
\text { multiple } \\
\text { regression model }\end{array}$ & $\begin{array}{l}\text { A negative relationship between } \\
\text { inventory turnover, inventory } \\
\text { conversion period and storage cost } \\
\text { with profitability, and inventory } \\
\text { level was found to be directly } \\
\text { related to firm's size and storage } \\
\text { cost }\end{array}$ \\
\hline $\begin{array}{l}\text { Tauseef, Lohano and } \\
\text { Khan (2015) }\end{array}$ & $\begin{array}{l}\text { Effect of debt financing on } \\
\text { corporate financial } \\
\text { performance: Evidence from } \\
\text { textile firms in Pakistan }\end{array}$ & $\begin{array}{l}\text { Simple } \\
\text { regression }\end{array}$ & $\begin{array}{l}\text { A non-linear relationship exists } \\
\text { between return on equity and debt- } \\
\text { to-asset ratio. }\end{array}$ \\
\hline $\begin{array}{l}\text { Tauseef, Lohano and } \\
\text { Khan (2015) }\end{array}$ & $\begin{array}{l}\text { Effect of debt financing on } \\
\text { corporate financial } \\
\text { performance: Evidence from } \\
\text { textile firms in Pakistan }\end{array}$ & $\begin{array}{l}\text { Simple } \\
\text { regression } \\
\text { Analysis }\end{array}$ & $\begin{array}{l}\text { A non-linear relationship exists } \\
\text { between return on equity and debt- } \\
\text { to-asset ratio. As the debt-to-asset } \\
\text { ratio increases, initially the return } \\
\text { on equity increased until an optimal } \\
\text { debt level was reached, after that it } \\
\text { started to decrease. }\end{array}$ \\
\hline $\begin{array}{l}\text { Ferreira, Matos and } \\
\text { Pires (2017) }\end{array}$ & $\begin{array}{l}\text { Asset Management within } \\
\text { Commercial Banking Groups: } \\
\text { International Evidence }\end{array}$ & $\begin{array}{l}\text { Field study and } \\
\text { observation }\end{array}$ & $\begin{array}{l}\text { Performance of externally-funded } \\
\text { investment is driven by the post- } \\
\text { financing value/redeploy-ability of } \\
\text { the Örmís assets outside of the } \\
\text { Örm. }\end{array}$ \\
\hline
\end{tabular}

Source: Researchers compilation, 2019

The review revealed that most of the studies were either foreign experiences (i.e. outside Nigeria) or that they were not actually based on building and construction companies in Nigeria. This is the gap that exists between the works of the other researchers and this study which the researcher intends to fill. 


\section{Research Design}

\section{METHODOLOGY}

This study is based on ex-post facto research design (i.e. research design that makes use of existing historical data).

\section{Sources of Data}

This study made use of secondary data extracted from annual reports of selected construction companies in Nigeria.

\section{Population of the Study}

The population of interest is the Nigerian construction industry numbering about 253 Building and Construction companies (See Appendix).

\section{Sample Size Determination}

Because of the large size of the sample of building and construction companies, a nonprobability sampling technique called convenience sampling technique was used to select three firms considering the researcher's convenience without taking note of statistical representativeness of the sample on the population' (Onyekwelu, 2015 pp. 148).

\section{Model Specification}

This study based its analysis on the following implicit linear regression models:

$\mathrm{Y}_{\mathrm{i}}=\alpha+\beta_{\mathrm{i}}\left(\mathrm{TATO}_{\mathrm{i}}\right)+\mathrm{e}$

$\mathrm{Y}_{\mathrm{i}}=\alpha+\beta_{\mathrm{i}}\left(\mathrm{INTO}_{\mathrm{i}}\right)+\mathrm{e}$

$Y_{i}=\alpha+\beta_{i}\left(W_{C T O}\right)+e$

\section{Description of variables in the model}

The variables in the models are expressed as follows:

$Y_{i}$ represents annual profit for the year i.e. dependent variable (used as proxy for performance) $\mathrm{TATO}_{\mathrm{i}}$ represents annual Total Assets Turnover

INTO $_{\mathrm{i}}$ represents annual Inventory Turnover

$\mathrm{WCTO}_{\mathrm{i}}$ represents annual Working Capital Turnover

$\alpha$ is the constant value in the estimation of profit after tax

$\beta_{i}$ represents the annual rate of change or variation in the total assets turnover, inventory turnover, and working capital turnover (the independent variables) respectively.

$e_{i}$ is the error term in the estimation of the dependent variable.

\section{Method of Data Analysis}

The study adopted the simple regression method of analysis and the SPSS version 20.0 was used for that purpose. 


\section{CHAPTER FOUR \\ PRESENTATION AND ANALYSIS OF DATA}

\section{Presentation of Data}

\begin{tabular}{ccccc}
$\begin{array}{c}\text { Table 4.1: } \\
\text { Year }\end{array}$ & $\begin{array}{c}\text { Aggregates of Data obtained } \\
\text { Total Asset } \\
\text { Turnover } \\
\text { Ratio }\end{array}$ & $\begin{array}{c}\text { fnventory } \\
\text { Turnover } \\
\text { Ratio }\end{array}$ & $\begin{array}{c}\text { the selected construction companies } \\
\text { Working Capital } \\
\text { Turnover Ratio }\end{array}$ & $\begin{array}{c}\text { Profit for the } \\
\text { Year } \\
\text { N'000 }\end{array}$ \\
2006 & 3.95 & 1.87 & 8.91 & $4,273,338$ \\
2007 & 14.44 & 12.73 & 7.27 & $3,749,690$ \\
2008 & 18.74 & 18.31 & 1.97 & $2,960,800$ \\
2009 & 2.99 & 28.77 & -2.21 & $4,816,523$ \\
2010 & 3.12 & 18.84 & 9.77 & $5,685,688$ \\
2011 & 2.15 & 21.80 & 14.68 & $8,417,275$ \\
2012 & 2.42 & 24.57 & 26.39 & $13,468,862$ \\
2013 & 1.93 & 25.25 & 9.09 & $8,292,986$ \\
2014 & 2.11 & 26.29 & 14.55 & $12,452,732$ \\
2015 & 1.76 & 21.26 & 8.49 & $6,756,683$ \\
2016 & 9.44 & 21.46 & 41.39 & $25,402,964$ \\
2017 & 6.84 & 19.97 & 27.36 & -9275961 \\
\hline
\end{tabular}

Source: Aggregate of Appendices A, B and C (see appendix for the original data)

\section{Analysis of Data}

\section{Hypothesis 1}

$\mathbf{H}_{0}$ : Total Asset turnover does not have significant effect on corporate performance of building and construction companies in Nigeria

Decision rule: Accept $\mathrm{H}_{0}$ if $\mathrm{p}$-value $>0.05$, otherwise reject

Table 5: Correlation Analysis on Profitability and Total Asset Turnover Model Summary

\begin{tabular}{|l|r|r|r|r|}
\hline Model & R & R Square & $\begin{array}{c}\text { Adjusted R } \\
\text { Square }\end{array}$ & $\begin{array}{c}\text { Std. Error of the } \\
\text { Estimate }\end{array}$ \\
\hline 1 & $.134^{\mathrm{a}}$ & .018 & -.080 & 8402306.168 \\
\hline
\end{tabular}

a. Predictors: (Constant), TATO

The result shows that at $r=0.134$ or $13.4 \%$; there is a positive but a very weak correlation between profitability and total asset turnover of manufacturing companies in Nigeria. This also shows that $r^{2}=0.018$, i.e. total asset turnover could only explain or determine $1.8 \%$ of the variations in profitability of building and construction companies in Nigeria for the period under study.

Table 6: Test of hypothesis on hypothesis 1 ANOVA $^{\mathrm{a}}$

\begin{tabular}{|ll|c|c|c|c|c|}
\hline Model & & Sum of Squares & Df & Mean Square & F & p-value \\
\hline \multirow{2}{*}{1} & Regression & 12965182360562.060 & 1 & 12965182360562.060 & .184 & $.677^{\mathrm{b}}$ \\
& Residual & 705987489354616.600 & 10 & 70598748935461.660 & & \\
& Total & 718952671715178.600 & 11 & & & \\
\hline
\end{tabular}

a. Dependent Variable: PAT

b. Predictors: (Constant), TATO

Decision: Table 6 shows that $p$-value $=0.677>0.05$. Therefore, we accept $\mathrm{H}_{0}$ and conclude that total asset turnover had no significant effect on profitability of building and construction companies in Nigeria between 2006 and 2017. 
Table 7: Regression of Profitability on Total Asset Turnover Coefficients ${ }^{\mathbf{a}}$

\begin{tabular}{|rl|r|r|r|r|r|}
\hline \multirow{2}{*}{ Model } & \multicolumn{2}{|c|}{ Unstandardized Coefficients } & \multicolumn{1}{|c|}{$\begin{array}{c}\text { Standardized } \\
\text { Coefficients }\end{array}$} & \multirow{2}{*}{ T } & -value \\
\cline { 3 - 5 } & \multicolumn{1}{|c|}{ B } & \multicolumn{1}{|c|}{ Std. Error } & \multicolumn{1}{c|}{ Beta } & & \\
\hline \multirow{2}{*}{1} & (Constant) & 8379870.726 & 3582327.009 & & 2.339 & .041 \\
& TATO & -193974.370 & 452640.633 & -.134 & -.429 & .677 \\
\hline
\end{tabular}

a. Dependent Variable: PAT

The regression equation on profitability and total asset turnover is represented below:

$$
\mathrm{Y}_{\mathrm{i}}=8,379,870.726-193974.370\left(\mathrm{TATO}_{\mathrm{i}}\right)+\mathrm{e}_{\mathrm{i}}
$$

This means that PAT grew at a constant value of $\mathrm{N} 8,379,870,726$ (significant contribution) and decreased marginally with $\mathrm{N} 193,974,370$ during the years under consideration.

\section{Hypothesis 2}

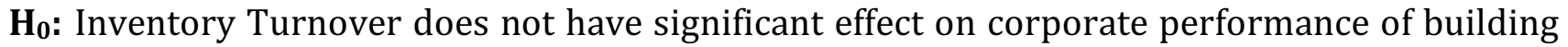
and construction companies in Nigeria

Decision rule: Accept $\mathrm{H}_{0}$ if $\mathrm{p}$-value $>0.05$, otherwise reject

Table 8: Correlation Analysis on Profitability and Inventory Turnover Model Summary

\begin{tabular}{|l|r|r|r|c|}
\hline Model & \multicolumn{1}{|c|}{$\mathrm{R}$} & R Square & \multicolumn{1}{c|}{$\begin{array}{c}\text { Adjusted R } \\
\text { Square }\end{array}$} & $\begin{array}{c}\text { Std. Error of the } \\
\text { Estimate }\end{array}$ \\
\hline 1 & $.641^{\mathrm{a}}$ & .410 & .351 & 6511296.620 \\
\hline
\end{tabular}

a. Predictors: (Constant), INTO

Table 8 shows that profit after tax has a positive and a high correlation (i.e. $r=0.641$ or $64.1 \%$ ) with inventory turnover of the building and construction companies in Nigeria. However, the coefficient of determination, $\mathrm{r}^{2}$ is 0.410 . This means that inventory turnover determined the variation of profit after tax up to $41 \%$ during the period. It did not really show a strong determination of profitability as other unexplained variables may have accounted for whooping $59 \%$ of the total variation.

Table 9: Test of hypothesis on hypothesis 2

ANOVAa

\begin{tabular}{|ll|c|c|c|c|c|}
\hline Model & & Sum of Squares & Df & Mean Square & F & p-value \\
\hline \multirow{4}{*}{1} & Regression & 294982834920761.250 & 1 & 294982834920761.250 & 6.958 & $.025^{\mathrm{b}}$ \\
& Residual & 423969836794417.400 & 10 & 42396983679441.734 & & \\
& Total & 718952671715178.600 & 11 & & & \\
\hline
\end{tabular}

a. Dependent Variable: PAT

b. Predictors: (Constant), INTO

Table 9 reveals that $\mathrm{p}$-value $=0.029<0.05$. We reject $\mathrm{H}_{0}$ and conclude that inventory turnover had significant effect on corporate performance of building and construction companies in Nigeria during the period studied. 
Table 10: Regression Analysis of Profitability on Inventory Turnover Coefficients ${ }^{\mathrm{a}}$

\begin{tabular}{|rl|r|r|r|r|r|}
\hline \multicolumn{2}{|l|}{ Model } & \multicolumn{2}{|c|}{ Unstandardized Coefficients } & \multicolumn{1}{c|}{$\begin{array}{c}\text { Standardized } \\
\text { Coefficients }\end{array}$} & \multicolumn{1}{c|}{$\mathrm{T}$} & $\mathrm{p}$-value \\
\cline { 3 - 5 } & \multicolumn{1}{|c|}{$\mathrm{B}$} & \multicolumn{1}{c|}{ Std. Error } & \multicolumn{1}{|c|}{ Beta } & & \\
\hline \multirow{2}{*}{1} & (Constant) & 8927331.555 & 1984284.710 & & 4.499 & .001 \\
& INTO & -9073.507 & 3439.888 & -.641 & -2.638 & .025 \\
\hline
\end{tabular}

a. Dependent Variable: PAT

The regression equation for estimation of profitability is represented by the following model:

$$
Y_{i}=8927331.555+8927331.555\left(\text { INTO }_{i}\right)+e_{i}
$$

This implies that inventory turnover contributed an average of N8,927,331,555 and a negative variable or marginal contribution of $\mathrm{N} 9073,507$ over the period.

\section{Hypothesis 3}

$\mathbf{H}_{\mathbf{0}}$ : Working Capital Turnover does not have significant effect on corporate performance of building and construction companies in Nigeria.

Decision rule: Accept $\mathrm{H}_{0}$ if $\mathrm{p}$-value $>0.05$, otherwise reject.

Table 11: Correlation Analysis on Profitability and Working Capital Turnover Model Summary

\begin{tabular}{|l|r|r|r|c|}
\hline Model & $\mathrm{R}$ & R Square & $\begin{array}{c}\text { Adjusted R } \\
\text { Square }\end{array}$ & $\begin{array}{c}\text { Std. Error of the } \\
\text { Estimate }\end{array}$ \\
\hline 1 & $.453^{\mathrm{a}}$ & .205 & .126 & 7558801.633 \\
\hline
\end{tabular}

a. Predictors: (Constant), WCTO

The analysis in table 11 indicates a low correlation between profitability and working capital turnover. This means that with $\mathrm{r}^{2}=0.453$, working capital turnover explained the changes in profitability during the period at $45.3 \%$ and at $12.6 \%$ when adjusted. This indicates that working capital turnover during the period under study did not strongly determine the variation in profitability as a whopping $54.7 \%$ still remained unexplained.

Table 12: Test of hypothesis on Profitability and working capital turnover ANOVA $^{\mathrm{a}}$

\begin{tabular}{|c|c|c|c|c|c|c|}
\hline \multicolumn{2}{|c|}{ Model } & Sum of Squares & Df & Mean Square & $\mathrm{F}$ & p-value \\
\hline \multirow{3}{*}{1} & Regression & 147597850485468.940 & 1 & 147597850485468.940 & 2.583 & $.139 \mathrm{~b}$ \\
\hline & Residual & 571354821229709.600 & 10 & 57135482122970.960 & & \\
\hline & Total & 718952671715178.500 & 11 & & & \\
\hline
\end{tabular}

a. Dependent Variable: PAT

b. Predictors: (Constant), WCTO

Decision: Since p-value $>0.05$, we accept $\mathrm{H}_{0}$ and conclude that working capital turnover did not have significant effect on corporate performance of building and construction companies in Nigeria for the period studied. 
Table 13: Regression Analysis of Profitability on Working Capital Turnover Coefficients ${ }^{a}$

\begin{tabular}{|rl|r|r|r|r|r|}
\hline \multicolumn{2}{|l|}{ Model } & \multicolumn{2}{|c|}{ Unstandardized Coefficients } & \multicolumn{1}{|c|}{$\begin{array}{c}\text { Standardized } \\
\text { Coefficients }\end{array}$} & \multirow{2}{*}{$\mathrm{T}$} & $\mathrm{p}$-value \\
\cline { 3 - 5 } & \multicolumn{1}{|c|}{ B } & \multicolumn{1}{|c|}{ Std. Error } & \multicolumn{1}{c|}{ Beta } & & \\
\hline \multirow{2}{*}{1} & (Constant) & 3050994.535 & 3403964.019 & & .896 & .391 \\
& WCTO & 300546.616 & 186992.752 & .453 & 1.607 & .139 \\
\hline
\end{tabular}

a. Dependent Variable: PAT

Table 13 shows that $\beta_{0}=3050994.535$ and $\beta_{i}=300546.616$. So by substitution the equation becomes:

$$
\mathrm{Y}_{\mathrm{i}}=3,050,994.535+300,546.616\left(\mathrm{WCTO}_{\mathrm{i}}\right)+\mathrm{e}_{\mathrm{i}}
$$

It means that working capital turnover contributed an estimated N3,050,994,535 and a positive marginal contribution of $\mathrm{N} 300,546,616$ in a year. The two values are significant at 5\%.

\section{CHAPTER FIVE SUMMARY, CONCLUSION AND RECOMMENDATION}

\section{Summary of Findings}

The study revealed that:

1) Asset turnover has no significant effect on corporate performance of building and construction companies in Nigeria.

2) Inventory turnover has significant effect on corporate performance of building and construction companies in Nigeria.

3) Working capital turnover has no significant effect on corporate performance of building and construction companies in Nigeria.

\section{Conclusion}

The building and construction sector is an economically viable sector that needs all attention to make it contribute to economic development of Nigeria. This study has shown that asset management efficiency of building and construction companies is paramount to the corporate performance of building and construction companies in Nigeria. The findings have added knowledge to this subject matter and given a clear understanding of the topic for the benefit of management of assets in building and construction companies in Nigeria.

\section{Recommendations}

The following recommendations are related to the findings of the study:

1) Management of building and construction companies should continue to adopt modern techniques of asset management and turnover by concentrating on the size and value of their total assets so as to raise the level of corporate performance.

2) Building and construction companies should give more attention to managing inventory turnover in their operations to avoid tying down working capital and problem of wastages associated with materials.

3) Management of building and construction companies should improve on working capital turnover. They could do this by reducing current liability of a company while increasing the current assets of building and construction companies in Nigeria. 


\section{References}

Adamu, N., Zubairu, I.K., Ibrahim, Y.M. \& Ibrahim, A.M. (2011). Evaluating the impact of product diversification on financial performance of selected Nigerian construction firms, Journal of Construction in Developing Countries, 16(2), 91-114

Adeagbo, A. (2014). Overview of the building and construction sector in the Nigerian economy, JORIND, 12(2), 349-366

Akeem, L.B., Terer \& Kiyanju, M.W., \& Kayode, A.M. (2014). Effects of capital structure on firm's performance: Empirical study of manufacturing companies in Nigeria. Journal of finance and Investment Analysis, 3(4), 39-57.

Al-Ani, M.K. (2014). Effects of Assets Structure on the Financial Performance: Evidence from Sultanate of Oman. Journal of US-China Public Administration, 11(2), 170-179.

Borad, S.B. (2017). Fixed assets turnover ratio definition, available at https://efinancemanagement.com/financial-analysis/fixed-asset-turnover, retrieved on May 11, 2019.

Campello, M. (2005). Asset tangibility and corporate performance under external financing, available at https://www3.nd.edu/ finance/020601/news/Campello\%20Paper.pdf, on May 1, 2019

Carlucci, D. \& Schiuma, G. (2004). Managing knowledge for business performance improvement, Journal of Knowledge Management, 16(4), 515-522, doi: 10.1108/13673271211246103.

Davydoff, D., Gabaut, L. \& Naacke, G. (2011). The importance of asset management to the European economy. Observatoire De L'Epargne Européen, 1-30.

Ferreira, M. A., Matos, P. P. \& Pires, P. (2017). Asset management within commercial banking groups: International evidence. Darden Business School Working Paper No. 2543175, retrieved from SSRN: https://ssrn.com/abstract=2543175 or http://dx.doi.org/10.2139/ssrn.2543175, on May 2, 2019.

Hargrave, M. (2019). Inventory turnover ratio definition, retrieved from

https://www.investopedia.com/terms/i/inventoryturnover.asp, May 11, 2019.

Kenton, W. (2019). Working capital turnover definition, available at https://www.investopedia.com/terms/w/workingcapitalturnover.asp, retrieved on May 11, 2019.

Kenton, W. \& Hayes, A. (2019). Asset turnover ratio definition, available at https://www.investopedia.com/terms/a/assetturnover.asp, retrieved on May 10, 2019.

Mardiasmo, D., Tywoniak, S., Brown, K. \& Burgess, K. (2008). Asset management and governance: Analyzing vehicle fleets in asset-intensive organizations, In Brown, Kerry A. and Mandell, Myrna and Furneaux, Craig W. and Beach, Sandra, Eds. Proceedings Contemporary Issues in Public Management: The Twelfth Annual Conference of the International Research Society for Public Management (IRSPM XII), pp 1-20, Brisbane, Australia.

Massa, M. \& Zhang, L. (n.d.). The effects of the organizational structure on asset management, retrieved from http://faculty.insead.edu/massa/Research/FundStructure3new.pdf, on May 3, 2019.

Olatunji, T. E. \& Adegbite, T. A. (2014). Investment in fixed assets and firm profitability: Empirical evidence from the Nigerian banking sector. Asian Journal of Social Sciences and Management Studies, 1(3), 78-82.

Ongore, V.O. \& Kura, G.B. (2013). Determinants of financial performance of commercial banks in Kenya, International Journal of Economics and Financial Issues, 3(1), 237-252

Onyekwelu, U.L. (2015). Firm foundation in Accounting and Finance research, (1 ${ }^{\text {st }}$ ed.), Enugu: His Glory Publications.

My Accounting Course (n.d.). Inventory turnover ratio definition, available at https://www.myaccountingcourse.com/financial-ratios/inventory-turnover-ratio, assessed on May 11, 2019.

My Accounting Course (n.d.). Working capital ratio definition, available at https://www.accountingtools.com/articles/2017/5/13/working-capital-ratio, assessed on May 11, 2019

Peavler, R. (2017). Use of asset management ratios in financial ratio analysis, available at https://www.thebalance.com/use-asset-management-ratios-in-financial-ratio-analysis-393187, retrieved on May 9, 2019.

Rouse, M. (2015). Corporate performance, available at http://whatis.techtarget.com/definition/corporateperformance, retrieved on May 11, 2019.

Shah, M. \& Littlefield, M. (2009). Asset performance management: Aligning the goals of CFO's and Maintenance Managers, Aberdeen Group, retrieved from http://forpoint.com.au/.../Infor-EAM-WPAsset-PerformanceManagement-Aberdeen-Grou..., on May 3, 2019. 
Sitienei \& Memba (2015). The effect of inventory management on profitability of cement manufacturing companies in Kenya: A case study of listed cement manufacturing companies in Kenya. International Journal of Management and Commerce Innovations, 3(2), 111-119.

Tauseef, S., Lohano, H.D. \& Khan, S.A. (2015). Effect of debt financing on corporate financial performance: Evidence from textile firms in Pakistan. Pakistan Business Review, 903-916.

The Institute of Asset Management (n.d.). What is asset management? Available at https://theiam.org/What-isAsset-Management, retrieved on May 11, 2019.

The Local Government and Municipal Knowledge Base (2017). Asset management, available at http://www.lgam.info/asset-management/p/2, retrieved on May 11, 2019.

Vanier, D. (2001). Why industry needs asset management tools. ASCE Journal of Computing in Civil Engineering, 15(1), 35-43

Woodhouse, J. (2006). Asset Management: Concepts and Practices, available at http://reliabilityweb.com/articles/entry/asset_management_concepts_practices/Last, retrieved May 11, 2019.

\section{APPENDIX A}

$\begin{array}{lllcc}\text { Year } & \begin{array}{l}\text { Cotal Asset } \\ \text { turnover }\end{array} & \begin{array}{c}\text { Cappa and D'Alberto Plc } \\ \text { Inventory } \\ \text { Turnover } \\ \text { ratio }\end{array} & \begin{array}{c}\text { Working Capital } \\ \text { Turnover ratio }\end{array} & \begin{array}{c}\text { Profit for the } \\ \text { Year } \\ \text { N'000 }\end{array} \\ 2006 & 0.75 & 4.31 & 1.31 & 826,000 \\ 2007 & 0.73 & 6.29 & 0.96 & 833,990 \\ 2008 & 0.75 & 7.24 & 1.05 & 505,853 \\ 2009 & 0.89 & 6.23 & 1.28 & 614,401 \\ 2010 & 0.59 & 6.86 & 3.06 & 382,863 \\ 2011 & 0.73 & 6.73 & 3.0 & 673,453 \\ 2012 & 0.95 & 6.21 & 4.08 & 641,807 \\ 2013 & 0.77 & 7.92 & 2.99 & 680,018 \\ 2014 & 1.09 & 8.40 & 4.17 & 1,155,948 \\ 2015 & 1.03 & 8.32 & 4.20 & 1,158,765 \\ 2016 & 1.16 & 9.79 & 4.04 & 968,406 \\ 2017 & 1.32 & 6.40 & 2.43 & 3,311,312\end{array}$

Source: Annual reports of Cappa \& D'Alberto

\begin{tabular}{ccccc} 
Year & \multicolumn{5}{c}{$\begin{array}{c}\text { APENDIX B } \\
\text { Ashaka Cement Plc } \\
\text { Total Asset } \\
\text { Turnover } \\
\text { Inventory } \\
\text { Turnover } \\
\text { Ratio }\end{array}$} & $\begin{array}{c}\text { Working Capital } \\
\text { Turnover Ratio }\end{array}$ & $\begin{array}{c}\text { Profit for the } \\
\text { Year } \\
\text { N'000 }\end{array}$ \\
2006 & 0.68 & 1.78 & 3.72 & $3,378,000$ \\
2007 & 0.75 & 2.58 & 3.72 & $1,158,000$ \\
2008 & 0.85 & 2.98 & -0.23 & $2,519,000$ \\
2009 & 0.67 & 2.98 & -5.56 & 943,000 \\
2010 & 0.62 & 2.50 & 3.55 & $2,528,000$ \\
2011 & 0.64 & 2.26 & 8.18 & $3,332,000$ \\
2012 & 0.64 & 2.36 & 0.91 & $5,055,000$ \\
2013 & 0.32 & 3.30 & 1.21 & $2,824,311$ \\
2014 & 0.30 & 3.75 & 1.56 & $4,566,667$ \\
2015 & 0.25 & 3.86 & 1.42 & $2,761,246$ \\
2016 & 6.17 & 2.82 & 3.39 & $20,778,348$ \\
2017 & 3.48 & 3.18 & 0.73 & $13,223,626$
\end{tabular}

Source: Annual reports of Ashaka Cement plc 


$\begin{array}{ccccc}\text { Year } & \begin{array}{c}\text { APPENDIX } \\ \text { Total Asset } \\ \text { Turnover } \\ \text { Ratio }\end{array} & \begin{array}{c}\text { Julius Berger Nig. Plc } \\ \text { Inventory } \\ \text { Turnover } \\ \text { Ratio }\end{array} & \begin{array}{c}\text { Working Capital } \\ \text { Turnover Ratio }\end{array} & \begin{array}{c}\text { Profit for the } \\ \text { Year } \\ \mathbf{N}^{\prime} \mathbf{0 0 0}\end{array} \\ 2006 & 2.52 & 5.80 & 3.89 & 69,338 \\ 2007 & 13.96 & 3.36 & 2.59 & 1,763,700 \\ 2008 & 17.14 & 8.09 & 1.15 & 2,452,427 \\ 2009 & 1.43 & 8.29 & 2.07 & 3,259,122 \\ 2010 & 1.91 & 9.48 & 3.16 & 2,774,825 \\ 2011 & 0.78 & 12.81 & 3.50 & 4,411,820 \\ 2012 & 0.89 & 16.0 & 21.40 & 7,772,055 \\ 2013 & 0.84 & 14.03 & 14.68 & 4,788,637 \\ 2014 & 0.72 & 14.14 & 37.93 & 6,730,117 \\ 2015 & 0.48 & 9.08 & 2.97 & 2,536,672 \\ 2016 & 2.11 & 8.85 & 33.96 & 3,656,210 \\ 2017 & 2.04 & 10.39 & 24.20 & 636,353 \\ & \text { Source: Annual reports of Julius Berger Plc } & \end{array}$

